\title{
Historical Learning Model Design Based on Critical Literation in The Era and Post Covid-19
}

\author{
Nabillah Mahdiana, Sariyatun, Hieronymus Purwanta \\ Universitas Sebelas Maret \\ nabillahmahdiana@student.uns.ac.id
}

Article History

accepted 1/09/2020

approved 4/10/2020

published 1/12/2020

\begin{abstract}
This research is motivated by the situation during the Covid-19 period which affects all sectors of life, including in the world of education. Teachers and students are required to be literate towards technology and literacy in learning to anticipate the spread of false information or hoaxes. The methodology used in this research is qualitative with descriptive analysis and data collection techniques in the form of a literature study. The findings of this study lead to the conclusion that the critical literacy-based historical learning model is important to apply because it is beneficial for teachers and students. The critical literacy learning model is designed with a critical pedagogical approach changing the wording hone critical thinking skills and to equip students with the skills to understand, critique texts critically, analytically, and evaluatively. While the benefits for teachers are an effort to improve the quality and effectiveness of learning by developing 21st-century competence.
\end{abstract}

Keywords: Learning design, historical learning model, critical literacy, Covid-19

\begin{abstract}
Abstrak
Penelitian ini di latarbelakangi oleh situasi pada masa Covid-19 yang mempengaruhi semua sektor kehidupan, termasuk dalam dunia pendidikan.Guru dan siswa di haruskan untuk melek terhadap teknologi dan literasi dalam pembelajaran untuk mengantisipasi penyebaran informasi yang salah, atau hoax. Metodologi yang di gunakan dalam penelitian ini adalah kualitatif dengan analisis deskriptif dan teknik pengumpulan data berupa studi kepustakaan. Temuan penelitian ini menghasilkan kesimpulan bahwa model pembelajaran sejarah berbasis literasi kritis penting untuk di terapkan karena bermanfaat bagi guru dan siswa. Model pembelajaran literasi kritis di desain dengan pendekatakan pedagogi kritis agar dapat mengasah keterampilan berpikir kritis serta untuk membekali siswa dengan keterampilan memahami, mengkriti teks secara kritis, analitis, dan evaluatif.Sedangkan manfaat bagi guru yakni sebagai upaya untuk meningkatkan kualitas, dan efektivitas pembelajaran dengan pengembangan kompetensi abad ke 21 .
\end{abstract}

Kata kunci : Desain pembelajaran, model pembelajaran sejarah, literasi kritis, Covid-19.

Social, Humanities, and Education Studies (SHEs): Conference Series https://jurnal.uns.ac.id/shes

p-ISSN 2620-9284

e-ISSN 2620-9292 


\section{PENDAHULUAN}

Pada bulan Januari 2020 WHO menyatakan dunia dalam keadaan darurat global terkait virus Covid-19. Beberapa tulisan pada pemberitaan media online menyebutkan bahwa terdapat 186 negara di dunia telah terjangkit oleh virus Covid-19 termasuk Indonesia (Tim Kerja Kementerian Dalam Negeri, 2020). Situasi pada masa Covid-19 telah mempengaruhi semua sektor kehidupan, termasuk dalam dunia pendidikan. Mendikbud mengeluarkan kebijakan nomor 4 tahun 2020 tentang kebijakan belajar dari rumah yang di lakukan melalui pembelajaran jarak jauh (Mendikbud RI,2020). Dengan dikeluarkannya edaran tersebut maka untuk melaksanakan pembelajaran dibutuhkan kebijakan, strategi dan inovasi baru dalam pembelajaran. Guru dan siswa di haruskan untuk melek terhadap teknologi dan literasi dalam pembelajaran untuk mengantisipasi penyebaran informasi yang salah, atau hoax.

Pemilihan strategi dan desain pembelajaran sejarah di masa pendemi Covid-19 harus tepat dan meyesuaikan dengan situasi dan kondisi. Desain pembelajaran sejarah yang di buat harus memaksimalkan pemanfaatan teknologi untuk mendukung kebijakan belajar dari rumah melalui pembelajaran jarak jauh. Pembelajaran sejarah di masa pendemi Covid-19 dapat dilakukan dengan menggunakan e-learning dengan etmodo atau memanfaatkan aplikasi zoom, googlemeet, google classroom, whatsapps, dan youtube. Pemanfaatan teknologi dalam pembelajaran sejarah telah merubah peran dan interaksi antara guru dengan siswa dalam pembelajaran. Oleh karena itu, desain pembelajaran sejarah dengan memanfaatkan teknologi harus mampu menciptakan ruang belajar yang dapat mendorong siswa untuk terlibat, aktif, kritis, dan mandiri. Pembelajaran sejarah dengan pemanfaatan teknologi menciptakan sistem pembelajaran modern learner sehingga pembelajaran lebih efektif dan memudahkan siswa untuk dapat belajar dari siapa saja, kapan saja dan dimana saja tanpa ada batasan.

Selain itu, desain pembelajaran sejarah di masa pendemi Covid-19 harus mampu mengembangkan keterampilan abad ke-21 antara lain meliputi : (1) penguasaan terhadap keterampilan literasi dasar, (2) kualitas karakter dan (3) kompetensi abad ke 21 (World Economic Forum, 2016). Pembelajaran sejarah di masa pendemi Covid-19 memerlukan penguasaan keterampilan abad ke-21 terutama penguasaan terhadap keterampilan literasi dasar. Penguasaan keterampilan literasi di masa pendemi Covid19 penting di kuasai oleh siswa untuk mendorong siswa agar memiliki keterampilan berpikir kritis sehingga selektif dalam menerima informasi serta mengantisipasi penyebaran informasi yang salah, atau hoax.

Di Indonesia, kemampuan berliterasi siswa pada tingkat menengah usia 15 tahun pemahaman membacanya rendah. Berdasarkan Hasil PISA 2018 Indonesia mengalami penurunan kemampuan membaca dibandingkan dengan hasil PISA Indonesia di tahun 2015. Hal ini dapat terlihat pada PISA 2015, menunjukkan bahwa kemampuan membaca siswa Indonesia berada pada peringkat ke-61 dari total 69 negara yang ikut berpartisipasi dalam PISA 2015. Perolehan skor rata - rata membaca PISA 2015 adalah 397 (OECD,2017). Sedangkan PISA 2018, menunjukkan bahwa kemampuan membaca siswa Indonesia berada pada peringkat ke-74 dari total 79 negara yang ikut berpartisipasi dalam PISA 2018. Perolehan skor rata - rata membaca PISA 2018 adalah 371 (OECD,2019). Dari kedua hasil ini dapat dikatakan bahwa kemampuan membaca siswa Indonesia dalam kategori rendah dan masih di bawah standart rata - rata kemampuan literasi membaca yang di tetapkan oleh OECD yakni 493 (OECD,2016).

Rendahnya kemampuan berliterasi siswa di Indonesia menunjukkan fakta bahwa siswa di Indonesia belum menguasai kecakapan hidup untuk bersaing dan bersanding dengan negara lain. Kemampuan literasi suatu bangsa menjadi tolak ukur kemampuan bangsa untuk berkolaborasi dan memenangi persaingan global. Rendahnya kemampuan berliterasi siswa dalam pembelajaran sejarah dapat di lihat dari rendahnya minat baca siswa dalam pembelajaran sejarah. Hal tersebut memberikan pengaruh 
terhadap rendahnya tingkat keterampilan berpikir kritis siswa. Rendahnya kemampuan berpikir kritis siswa di sebabkan karena proses pembelajaran sejarah yang dilakukan oleh guru di nilai kurang efektif untuk mengembangkan minat baca dan kesadaran kritis siswa. Pembelajaran sejarah yang di lakukan oleh guru belum bisa melatih kemampuan berpikir kritis siswa terutama dalam menyelesaikan soal - soal yang bersifat kontekstual, dengan melibatkan argumentasi dan penalaran.

Upaya yang dapat dilakukan untuk mengatasi masalah rendahnya kemampuan literasi siswa dalam pembelajaran sejarah di masa pendemi Covid-19 adalah dengan menerapkan model pembelajaran sejarah berbasis literasi kritis dengan memanfaatkan teknologi melalui sistem pembelajaran jarak jauh. Model pembelajaran sejarah berbasis literasi kritis di pilih karena model pembelajaran literasi kritis dapat membentuk siswa untuk menjadi pemikir kritis, membangun kepercayaan diri peserta didik dalam menemukan kebenaran dari banyaknya peristiwa dan informasi setiap hari, serta melatih siswa untuk merumuskan dan mengevaluasi bukti, asumsi, logika, dan bahasa yang mendasari pernyataan orang lain. Model pembelajaran sejarah berbasis literasi kritis dengan memanfaatkan teknologi melalui sistem pembelajaran jarak jauh dapat meningkatkan kualitas pembelajaran sejarah terutama dalam menguasai kompetensi abad ke -21 yakni berpikir kritis.

\section{METODE}

Penelitian ini menggunakan metode kualitatif dengan analisis deskriptif dan teknik pengumpulan data berupa studi kepustakaan berupa buku - buku dan jurnal yang relevan dalam penelitian. Metode kepustakaan merupakan metode pengumpulan data yang bertumpu pada penelaahan kritis dan mendalam terhadap sumber kepustakaan yang relevan sehingga memperoleh data yang bersifat teoritis (Sukmadinata,2007).

\section{Pengertian Literasi Kritis}

\section{HASIL DAN PEMBAHASAN}

Literasi menurut National Institute for Literacy dalam Priyatni (2012) merupakan kemampuan individu untuk membaca, berbicara, menghitung dan memecahkan suatu masalah pada tingkat keahlian yang diperlukan dalam pekerjaan, keluarga, dan masyarakat. Kirsch \& Jungeblut di dalam buku Literacy: Profile of America's Young Adult menyebutkan bahwa literasi adalah kemampuan seseorang dalam menggunakan informasi untuk mengembangkan pengetahuan sehingga mendatangkan manfaat bagi masyarakat. Literasi berkaitan dengan kemampuan seseorang dalam memahami, menggunakan, dan merefleksikan bacaan tertulis untuk mencapai tujuan sesuai dengan keperluan, mengembangkan pengetahuan dan potensi, serta berpartisipasi dalam masyarakat.

Gerakan Literasi Nasional (2016) dalam bukunya menyebutkan makna dan cakupan literasi meliputi: (a) literasi sebagai rangkaian kecakapan membaca, menulis, berbicara, kecakapan berhitung, dan kecakapan dalam mengakses dan menggunakan informasi; (b) literasi sebagai praktik sosial yang penerapannya dipengaruhi oleh konteks; (c) literasi sebagai proses pembelajaran dengan kegiatan membaca dan menulis sebagai medium untuk merenungkan, menyelidik, menanyakan, dan mengkritisi ilmu dan gagasan yang dipelajari, (d) literasi sebagai teks yang bervariasi menurut subjek, genre, dan tingkat kompleksitas bahasa. Literasi di pandang sebagai konstruksi sosial yang tidak pernah netral karena teks selalu di bentuk berdasarkan posisi penulis,serta di pengaruhi oleh banyak aspek seperti nilai - nilai, keyakinan, sikap, pendidikan dan latar belakang dari penulis. Oleh karena itu, sangat penting bagi seseorang untuk memiliki kemampuan literasi kritis (Abidin,2018).

Literasi kritis merupakan kemampuan seseorang untuk memecahkan kode makna teks, berpartisipasi dalam memahami dan menyusun teks yang bermakna, mengunakan 
teks secara fungsional dan pada akhirnya analisis teks secara kritis ( Luke and Freebody,2002). Banyak peneliti yang mendefinisikan literasi kritis secara luas seperti: Siegel (1995), Unsworth (2001), Pappas, Kiefer, \& Levstik (2005) dan lainnya mengungkapkan bahwa, literasi kritis mengacu pada proses emansipatoris yang orang tidak hanya membaca kata tetapi juga dunia, suatu proses di mana seseorang menjadi diberdayakan untuk dapat mengungkap dan memecahkan kode, dimensi ideologis teks, institusi, praktik sosial dan bentuk budaya.

\section{Desain Model Pembelajaran Sejarah Berbasis Literasi Kritis di SMA}

Model Pembelajaran merupakan gambaran langkah - langkah atau prosedur yang perlu di tempuh untuk menciptakan aktivitas pembelajaran yang efektif, efisien, dan menarik (Benny,2009). Salah satu model pembelajaran sejarah yang bisa di terapkan di masa pendemi Covid-19 adalah model pembelajaran sejarah berbasis literasi kritis. Model pembelajaran sejarah berbasis literasi kritis merupakan suatu model pembelajaran aktif dan konstruktif yang didesain dengan menggunakan pendekatan pedagogi kritis untuk membekali siswa dengan keterampilan memahami, mengkriti teks secara kritis, analitis, dan evaluatif (Abidin,2018). Melalui model literasi kritis maka tercipta pembelajaran sejarah yang kontekstual dan kritis. Model literasi kritis membiasakan siswa untuk membangun pengetahuannya sendiri, berdasarkan konteks nyata yang bermakna bagi siswa. Model literasi kritis menggunakan metode pembacaan sebuah teks dengan mengaitkan teks dan konteks sehingga melatih siswa untuk bersikap kritis terhadap apa yang dibaca, serta melatih siswa untuk dapat memahami dan menghubungkan informasi dan pengetahuan sesuai dengan konteknya.

Literasi kritis menjadi keterampilan yang sangat penting untuk bertahan hidup di abad ke-21 yang padat informasi (Lee,2015). Pembelajaran sejarah berbasis literasi kritis bertujuan untuk membangun kesadaran kritis siswa terutama dalam menggunakan informasi dan pengembangan pengetahuan dengan cara melatih kemampuan siswa untuk mengkritik teks berdasarkan sudut pandang yang berbeda untuk mempertanyakan keotoritasan yang telah banyak diakui (Ciardiello,2004). Pembelajaran sejarah berbasis literasi kritis memainkan peran penting untuk membantu siswa dalam memahami dunia dari berbagai hal dan perspektif termasuk memahami masalah politik, ekonomi, dan masalah sosial (Knobel \& Lankshear,2002). Pembelajaran berbasis literasi kritis menumbuhkan kesadaran kritis siswa sehingga siswa akan termotivasi untuk meningkatkan keterampilan berpikir kritis melalui kegiatan bertanya, berdiskusi, mengevaluasi, membuat kesimpulan dari apa yang telah di baca.

Hal yang dilakukan sebelum merancang desain pembelajaran sejarah berbasis literasi kritis adalah dengan memahami karakteristik pembelajaran sejarah antara lain : (1) Pembelajaran sejarah yang di rancang hendaknya dapat menumbuhkan kesadaran kritis siswa, dengan cara melatih siswa berpikir kritis dan kreatif. (2) Membangun kesadaran sejarah dari berbagai perspektif melalui pengembangan keterampilan berpikir kesejarahan. (3) Pembelajaran sejarah hendaknya berorientasi pada penanaman nilai. (4) Melatih intektual siswa agar mampu memahami realita kehidupan masyarakat yang sebenarnya melalui praktik pembelajaran yang kontekstual dan konstruktif dengan pembiasaan agar siswa terlatih memahami konsep - konsep induktif - deduktif dan membuat generalisasi.

Setelah memahami karakteristik pembelajaran sejarah selanjutnya guru mulai menyusun rancangan pembelajaran sejarah berbasis literasi kritis di era pendemi Covid19. Terdapat empat kegiatan merancang model desain pembelajaran sejarah antara lain

1. Menyusun Rencana Pembelajaran

Langkah pertama yang di lakukan guru sebelum merencanakan pembelajaran yakni guru menyesuaikan dengan Kompetensi Inti (KI) dan Kompetensi Dasar (KD) 
pembelajaran. Didalam praktik pembelajaran sejarah berbasis literasi kritis ada beberapa keterampilan dasar yang harus di miliki oleh siswa antara lain :

Pertama, membuat koneksi merupakan keterampilan sentral yang diperlukan untuk pengembangan keterampilan yang mendasar bagi literasi kritis. Membuat koneksi dapat membawa siswa ke tingkat pemahaman dan pemikiran yang lebih dalam yang memungkinkan siswa untuk berpikir kritis. Membuat koneksi terjadi ketika pembaca menghubungkan apa yang mereka baca dengan pengalaman pribadi (teks ke diri sendiri), dengan informasi dari teks lain (teks ke teks), dan informasi tentang dunia (teks ke dunia) untuk meningkatkan pemahaman diri, teks, dan kehidupan (WECB, 2006 2013).

Kedua, mengambil kesimpulan terjadi ketika siswa memikirkan dan mencari teks, dengan menggunakan pengetahuan pribadinya untuk membangun makna di luar apa yang dinyatakan (WECB, 2006 - 2013). Ketiga, membuat pertanyaan sebelum, selama, dan setelah membaca diperlukan agar siswa mendapatkan pemahaman yang mendalam (Hassett,2008). Membuat pertanyaan membantu siswa untuk membaca dan memahami dunia sehingga kesadaran kritis siswa dapat di tingkatkan melalui pertanyaan yang di ajukan serta pengalaman yang pernah di rasakan.

Keempat, memvisualisasikan terjadi ketika siswa membuat gambar (peta konsep) yang mewakili ide - ide dalam teks. Gambar - gambar ini dapat di lihat oleh panca indera dan berfungsi untuk meningkatkan pemahaman teks (WECB, 2006 - 2013). Kelima, mensintesis dapat dilakukam dengan melakukan penyelidikan atau penelitian sederhana, membuka ruang berdiskusi untuk mendorong peserta didik maju pada level berpikir, melakukan wawancara kelompok untuk menciptakan wawasan, perspektif, dan pemahaman dengan merefleksikan teks dan menggabungkan elemen dari teks dan skema yang ada (WECB, 2006 - 2013).

Selanjutnya langkah kedua dari merencanakan pembelajaran adalah menentukan tujuan pembelajaran yang hendak di capai dan mengembangkan indikator pembelajaran. Tujuan pembelajaran sejarah di SMA antara lain : (1) menanamkan semangat cinta tanah air, (2) mengetahui proses terbentuknya Negara Indonesia, (3) meningkatkan rasa persatuan dan kesatuan bagi siswa, dan (4) mengetahui proses peradaban manusia Indonesia khususnya dan masyarakat dunia pada umumnya dari masa dulu hingga sekarang. (Leo Agung,2013). Kemudian menentukan model, dan teknik pembelajaran. Model pembelajaran sejarah yang dapat di terapkan di era pendemi Covid-19 adalah model literasi kritis. Teknik pembelajaran sejarah berbasis literasi kritis dilakukan dengan menggunakan pembelajaran daring jarak jauh melalui pemanfaatan teknologi seperti: e-learning dengan etmodo atau memanfaatkan aplikasi zoom, googlemeet, google classroom, whatsapps, dan youtube.

2. Pengembangan Materi Pembelajaran

Pemilihan materi bisa di sesuaikan dengan kondisi dan situasi saat pendemi Covid-19. Guru bisa memilih materi mengenai sejarah wabah pendemi seperti wabah Kolera dan Black Death yang pernah melanda dunia dan memberikan dampak pengaruh besar terhadap dunia. Selain itu, guru juga dapat memilih materi sejarah lokal. Model desain literasi kritis yang di buat adalah model pembelajaran jarak jauh atau daring sehingga guru harus memberikan kebebasan siswa untuk membangun pengetahuannya sendiri dengan cara memperbolehkan siswa untuk mencari tau sendiri informasi dari berbagai sumber, membiarkan siswa terlibat aktif dan mandiri dalam memilah keberagaman informasi, dan memilah informasi dari berbagai sudut pandang dan perspektif. Hal ini bertujuan untuk melatih dan membiasakan siswa untuk mandiri, serta punya keterampilan berpikir kritis, analitis, dan evaluatif. Guru juga sebelumnya harus sudah menjelaskan metode penulisan sejarah agar siswa dapat menerapkan metode sejarah seperti Heuristik, Kritik, Interpretasi, dan Historiografi dalam menulis sejarah wabah pendemi atau sejarah lokal. Penggunaan metode sejarah melatih siswa untuk 
lebih teliti dalam mencari sumber informasi yang valid dan kredibel sehingga mengantisipasi informasi yang salah atau hoax.

\section{Menyusun Kegiatan Belajar}

Kegiatan pembelajaran sejarah di desain sesuai dengan tahapan dan sintaks model literasi kritis. Terdapat tiga tahap dalam pembelajaran sejarah berbasis literasi kritis antara lain:

Pertama, tahap pra-baca (problematisasi) merupakan tahap pembelajaran literasi dalam konteks konkret dan konteks teoritis. Pada tahap pra baca guru berusaha untuk menggali skemata siswa dengan cara menyajikan suatu teks sejarah dan gambar. Kedua, tahap membaca (diskusi kultural) merupakan tahap yang di awali dengan siswa mencari dan membaca informasi dari beragam sumber. Siswa akan mencari dan mengungkap keterkaitan antara teks dan konteks. Pada tahap membaca, guru bertugas untuk membagi siswa menjadi beberapa kelompok grup diskusi, kemudian siswa di minta untuk membaca informasi dari berbagai sumber. Ketiga, tahap pasca-baca (tindakan sosial) merupakan suatu tahap setelah membaca yang di awali dengan kegiatan penyelidikan terhadap kebenaran temuan fakta, opini, serta fenomena sosial. Setelah itu siswa di minta untuk mempertanyakan realitas kebenaran teks sejarah. Guru meminta siswa untuk mengkritisi dan menilai kebenaran teks sejarah secara kritis (Hendriani, Nuryani, Ibrahim, 2017).

Desain pembelajaran sejarah berbasis literasi kritis mendorong siswa untuk membangun kesadaran kritis siswa, serta mengembangkan narasi dan argumentasi siswa. Model literasi kritis berfokus pada kedalaman analisis bukan keluasan materi. Langkah prosedural model literasi kritis di bagi menjadi delapan langkah antara lain : (Abidin, 2018)

a. Curah Gagasan

Guru dan siswa bersama menentukan materi atau sebuah fenomena sosial yang akan dibahas di dalam pembelajaran.

b. Menetapkan Masalah

Guru dan siswa bersama menetapkan permasalah dari materi atau fenomena sosial yang akan di kajinya selama pembelajaran. Guru membebaskan siswa untuk mencari beragam informasi mengenai fenomena sosial yang sudah di sepakati sebelumnya.

c. Membaca Teks

Siswa membaca seksama informasi yang telah di dapatkan dari beragam sumber seperti sumber buku, jurnal dan internet.

d. Menemukan Fakta dan Opini

Berdasarkan teks yang telah dibacanya siswa mencatat temuan fakta dan opini. Jika siswa belum bisa memahami fakta dan opini guru dapat menugaskan siswa untuk mencatat hal - hal yang menarik bagi siswa.

e. Menguji Fakta dan Opini

Setelah siswa mencatat dan mengklasifikasikan fakta dan opini, kemudian siswa menguji validitas dan kredibilitas kebenaran informasi yang di dapatnya tersebut. Guru dapat memberikan penjelasan tentang konsep fakta dan opini sehingga siswa tidak melakukan kesalahan dalam menguji kedua hal tersebut.

f. Menetapkan Fenomena Sosial

Setelah siswa dapat menemukan, membedakan, dan menguji fakta dan opini maka siswa menetapkan fenomena sosial yang akan di tulis, lalu siswa membuat generalisasi yang menghubungkan fenomena sosial dengan konteks sosial.

g. Menganalisis Fenomena Sosial 
Siswa menganalisis dan membuat kesimpulan mengenai fenomena sosial, selanjurnya siswa di minta guru untuk dapat merumuskan bagaimana cara terbaik untuk mengatasi fenomena sosial tersebut.

h. Memproduksi Karya

Kemudian rumusan pemecahan terhadap fenomena sosial yang dibuat pada tahap sebelumnya dikembangkan menjadi sebuah teks atau tulisan baru yang berbentuk argumentatif.

\section{Penilaian Otentik}

Guru melakukan penilaian otentik untuk mengukur hasil belajar siswa dalam ranah sikap, pengetahuan, dan keterampilan. Dalam praktiknya model literasi kritis penilaiannya meliputi: (1) keterampilan berpikir untuk mengukur kemampuan siswa dalam memahami, menginterpretasi, menganalisis, menguji, dan mengevaluasi, (2) penilaian sikap kritis yang di tunjukkan siswa dalam pembelajaran, (3) penilaian terhadap proses, (4) penilaian kinerja siswa dan (5) penilaian terhadap hasil produk siswa.

\section{SIMPULAN}

Model pembelajaran sejarah berbasis literasi kritis merupakan suatu model pembelajaran aktif dan konstruktif yang didesain dengan menggunakan pendekatan pedagogi kritis untuk membekali siswa dengan keterampilan memahami, mengkriti teks secara kritis, analitis, dan evaluatif. Melalui model literasi kritis maka tercipta pembelajaran sejarah yang kontekstual dan kritis sehingga mendorong keterampilan siswa untuk berpikir kritis serta mengembangkan narasi dan argumentasi siswa. Prosedur dalam merancang model literasi kritis antara lain : (1) menyusun rancangan pembelajaran berbasis literasi, (2) pengembangan materi pembelajaran, (3) menyusun kegiatan pembelajaran berbasis literasi, dan (4) penilaian otentik.

\section{DAFTAR PUSTAKA}

Abidin, Yunus. 2015. Pembelajaran Multiliterasi: Sebuah Jawaban atas Tantangan Pendidikan Abad Ke -21 dalam konteks Keindonesiaan. Bandung: PT Refika Aditama Agung, Leo. 2013. Pengembangan Model Pembelajaran Sejarah SMA Berbasis Pendidikan Karakter Di Solo Raya. Jurnal Pendidikan dan Kebudayaaan, 18(4), 412- 426.https://doi.org/10.24832/jpnk.v18i4.98

Cheu-Jey Lee. 2015. Habermasian Criteria For Critical Literacy: Examples Of Critical Text Analysis And Their Implications. International Journal of Critical Pedagogy | Vol. 6 No. 2

Ciardiello, A. V. 2004. Democracy's young heroes: An instructional model of critical literacy practices. Reading Teacher, 58, 138-147

Hendriani, Ani, Nuryani, P, Ibrahim T. 2018. Pedagogik Lierasi Kritis; Sejarah, Filafat Dan Perkembangannya Di Dunia Pendidikan. PEDAGOGIA 16(1),44-59 Kemendikmud. 2016. Buku Panduan Gerakan Literasi Sekolah untuk Sekolah Menengah Atas. Jakarta. Direktorat Jenderal Pendidikan Dasar dan Menengah Knobel, M., and Lankshear, C. 2002. Critical cyberliteracies: What young people can teach us about reading and writing in the world. Keynote address delivered to the National Council of Teachers of English Assembly for Research

Luke, A. \& Freebody, P. 1997. Critical literacy and the question of normativity: An 
introduction. In S. Muspratt, A. Luke \& P. Freebody (Eds.), Constructing critical literacies: Teaching and learning textual practices (pp. 1-18). Cresskill, NJ: Hampton Press.

Mendikbud RI. (2020). Surat Edaran Nomor 4 Tahun 2020 Tentang Pelaksanaan Kebijakan Pendidikan Dalam Masa Darurat Penyebaran Coronavirus Disease (COVID- 19). 1-3.

OECD .2006. Frame Work Programme International Students Assessment.Paris:

OECD

OECD.2017. PISA 2015 Results in Focus. Programme for International Student Assessment. OECD Pendit, P. L. (2017). Literasi. (Online) Qureta.com. Retrieved from https://www.qureta.

OECD.2019. PISA 2018 Results in Focus. Programme for International Student Assessment. OECD Pendit, P. L. (2019). Literasi. (Online) Qureta.com. Retrieved from https://www.qureta.

Pribadi, Benny. 2009. Model Desain Sistem Pembelajaran. Jakarta: PT Dian Rakyat Priyatni, Endah Tri. 2012. Membaca Sastra dengan Ancangan Literasi Kritis. Jakarta: Bumi Aksara

Tim Kerja Kementerian Dalam Negeri. 2020. Pedoman Umum Menghadapi Pandemi Covid-19. Diakses 25 September 2020

Wisconsin Educational Communications Board (WECB). (2006-2013). Into the book. Online di http://reading.ecb.org/teacher/strategies.html

Word Economic Forum. 2016. "What are the 21st-century skills every student needs?". Retrieved from https://www.weforum.org/agenda/2016/03/21st-century-skillsfuture- jobs-students/ 